Original Research Paper

\title{
Edukasi Ramah Anak Melalui Program Pengabdian Masyarakat Universitas Mataram untuk Mewujudkan Kelurahan Gomong Sehat dan Cerdas
}

\author{
Immy Suci Rohyani ${ }^{1}$, M. Wildane Ganevo ${ }^{2}$ \\ ${ }^{1}$ Program Stud Ilmu Lingkungan, FMIPA, Universitas Mataram, Mataram, Indonesia \\ ${ }^{2}$ Program Stud Pendidikan Kimia, FKIP, Universitas Mataram, Mataram, Indonesia
}

https://doi.org/10.29303/jpmpi.v3i2.939

Sitasi: Rohyani, I. S \& Ganevo, M. W. (2021). Edukasi Ramah Anak Melalui Program Pengabdian Masyarakat Universitas Mataram untuk Mewujudkan Kelurahan Gomong Sehat dan Cerdas. Jurnal Pengabdian Magister Pendidikan IPA, 4(3)

Article history

Received: 31 Juli 2021

Revised: 31 Agustus 2021

Accepted: 4 September 2021

*Corresponding Author:

Immy Suci Rohyani, Fakultas Matematika Dan Ilmu Pengetahuan Alam, Universitas Mataram, Mataram, Indonesia Email: $\underline{\text { immy2@unram.ac.id }}$

\begin{abstract}
Pada Era New Normal Pandemi Covid-19 ini masyarakat masih kebanyakan melakukan aktivitasnya dari rumah. Penerapan Kerja dari rumah dan pembelajaran dari rumah merupakan hal utama pada masa pandemi ini untuk memperkecil penyebaran covid-19. Penerapan protokol kesehatan merupakan hal utama dan kewajiban masyarakat saat ini. Mencuci tangan menggunakan sabun atau hand sanitizer, menggunakan masker dan menjaga jarak harus dioptimalkan dalam menekan angka penyebaran kasus covid-19. Masyarakat dan anak-ana di Kelurahan Gomong, masih banyak yang belum optimal dalam menerapkan protokol kesehatan Covid-19. Oleh karena itu perlu adanya edukasi yang optimal dengan pendekatan humanis dan ramah anak. Selain itu dengan diadakannya pembelajaran jarak jauh maka anak-anak memiliki kebosanan dan kesusahannya sendiri dalam menghadapi pembelajaran. Melalui Program Pengabdian Masyarakat Universitas Mataram ini dilakukannya Edukasi Ramah Anak dengan membantu anak belajar dan edukasi hal lain yang bermanfaat bagi anak serta menunjang psikologis anak tetap dapat merasakan riang gembira pada masa pandemi covid-19. Hal-hal yang dilakukan berupa Edukasi melalui alat Komunikasi Informasi dan Edukasi (KIE), Edukasi melalui Spanduk, Edukasi anak-anak secara langsun, pembagian 600 masker, serta pembentukan Forum Anak.
\end{abstract}

Keywords: Covid-19; Anak-anak; Edukasi.

informasi yang didapatkan di Situation Report WHO. Pada tanggal 8 Januari 2021 perkembangan kasus konfirmasi Covid-19 di Indonesia mencapai kumulatif 10.617 kasus, dimana tertinggi kumulatif kasus Covid-19 di Provinsi DKI Jakarta dengan jumlah 2.959 kasus dan terkecil kasus konfirmasi Covid-19 di Provinsi Maluku dengan jumlah 0 kasus (Kemenkes, 2020).

Saat ini segala aktifitas disarankan dilakukan dari rumah baik bekerja dari rumah maupun belajar dari rumah. Permasalahannya adalah dengan tidak ada aktifitas menuju kantor dan sekolah kebanyakan masyarakat dan anak-anak tetap pergi keluar rumah dengan alasan hal lain. Pembelajaran dari rumah sendiri telah diantisipasi 
oleh kemendikbud dengan pemberian bantuan kuota belajar dan adanya edukasi pembelajaran melalui TVRI. Kementerian Pendidikan dan Kebudayaan (Kemendikbud) telah resmi meluncurkan program "Belajar dari Rumah" sebagai alternatif anak belajar dari rumah selama pandemi Covid-19. Menteri Pendidikan dan Kebudayaan (Mendikbud) Nadiem Makarim ingin memastikan bahwa dalam kondisi darurat seperti sekarang ini masyarakat khususnya anak-anak terus mendapatkan kesempatan untuk melakukan pembelajaran di rumah, salah satunya melalui media televisi yaitu TVRI. (Kemendikbud, 2020).

Selain itu anak-anak juga mengalami masalah lain yaitu kejenuhan atau kebosanan saat harus berdiam diri dirumah dan juga merasa kesulitan melaksanakan pembelajaran dari rumah. Anak-anak membutuhkan bimbingan dalam belajar serta membutuhkan pembelajaran yang asik dan menarik untuk dapat mengerti hal itu. Minimal langkah yang dilakukan adalah bagaimana psikologis anak selama pandemi ini tetap terjaga dan anak-anak tetap merasakan kesenangannya sesuai dengan usianya. Masyarakat dan anak-anak di Kelurahan Gomong Kecamatan Selaparang Kota Mataram masih banyak yang lalai akan protokol kesehatan. Selain itu juga tampak anak-anak memiliki rasa bosan dalam belajar pada saat pandemi covid-19 ini hal tersebut dinyatakan oleh anak-anak itu sendiri dan pernyataan orang tua yang menyatakan cukup susah anak-anak untuk belajar bahkan orang tua juga terkadang tidak mengerti dengan pembelajaran sang anak.

Berdasarkan hal tersebut, tim penulis sebagai civitas akademika yang mengemban amanah Tri Dharma Perguruan Tinggi terpanggil untuk melaksanakan kegiatan yang dapat menunjang permasalahan dari latar belakang diatas. Melihat situasi di Kelurahan Gomong, tim penulis melakukan kegiatan Pengabdian Masyarakat Universitas Mataram Program Mengajar di Desa dengan Tema Edukasi Ramah Anak. Beberapa hal yang akan dilakukan sebagai solusi permasalah di atas adalah memberikan edukasi kepada masyarakat dan anak-anak terkait Protokol Kesehatan dan Covid-19 melalui beberapa cara yaitu secara langsung maupun dengan melalui media berupa alat Komunikasi, Informasi dan Edukasi (KIE), melalui spanduk dan pemberian masker serta penyemprotan hand sanitizer. Selain itu juga akan dilaksanakan proses belajar sebagai bentuk edukasi permasalahan pembelajaran anak dan peningkatan nilai religius anak melalui mengaji dan berdo'a. Sebagai bentuk pengembangan dan penerapan edukasi yang inovatif dan kreatif anak-anak juga diedukasi terkait materi yang mampu meningkatkan kapasitas anak baik itu literasi dan numerasi serta visualisasi terhadap anak. Anak juga diajarkan untuk mencintai lingkungannya dengan menanam bibit menggunakan media botol bekas serta mengolah sampah botol bekas dan kertas bekas menjadi barang berguna seperti hiasan dan juga kotak pensil.

\section{Metode}

Dalam melaksanakan kegiatan Edukasi Ramah Anak ini dilakukan beberapa metode yaitu dengan melakukan pendekatan humanis, pembelajaran yang ramah anak dan juga melaksanakan kegiatan berdasarkan minat dan bakat anak. Pada dasarnya kata "Humanistik" merupakan suatu istilah yang memiliki banyak makna sesuai dengan konteksnya. Misalnya, humanistik dalam mengedukasi terkait covid-19 dan protokol kesehatan maka pengedukasi harus pelan pelan dan penuh sabar menjelaskan terkait hal tersebut sesuai keadaan dan kondisi sosial budaya masyarakat tersebut. Di sisi lain humanistik berarti minat terhadap nilai-nilai kemanusiaan yang bersifat ketuhanan. Sedangkan humanistik dalam tataran akademik tertuju pada pengetahuan tentang budaya manusia, seperti studi-studi klasik (Qodir, 2017). Pendekatan humanistik ini adalah kerangka implementasi pendidikan yang ramah anak.

Hal senada juga diungkapkan oleh Yulianto (2016) bahwa pendidikan ramah anak adalah pendidikan yang anti diskriminasi, menerapkan edukasi inklusi, perhatian dan melindungi anak, lingkungan yang sehat, serta adanya partisipasi orangtua dan masyarakat. Selain itu Sholeh dkk (2016) menyatakan bahwa pendidikan ramah anak adalah suatu satuan lembaga pendidikan yang dapat memfasilitasi dan memberdayakan potensi anak.

Oleh karena itu penulis menerapkan pembelajaran yang anak inginkan seperti belajar membaca, menulis, berhitung, mengenal hewan, buah dan sayur serta menggambar dan mewarnai. Hal ini dilakukan agar pembelajaran menjadi lebih ramah anak sesuai dengan minat bakat anak. Selain itu juga dilakukan pengembangan nilai religius 
anak dengan mengajar mengaji kepada anak. Dalam meningkatkan kreatifitas dan kepedulian anak terhadap lingkungan maka diterapkan edukasi terkait pengolahan sampah menjadi barang yang lebih berguna dan juga mengajarkan kepada anak untuk mampu membibitkan sayur menggunakan media botol bekas.

\section{Hasil dan Pembahasan}

Program Pengabdian Masyarakat dilakukan di Kelurahan Gomong Kecamatan Selaparang Kota Mataram selama 45 hari yang dilaksanakan dari bulan November 2020 sampai Januari 2021. Program Mengajar di Desa yang dilaksanakan di lokasi mengabdi dengan menerapkan Tema Edukasi Ramah Anak. Kegiatan yang dilakukan berupa edukasi kepada masyarakat dan anak-anak terkait Protokol Kesehatan dan Covid-19 melalui beberapa cara yaitu secara langsung maupun dengan melalui media berupa alat Komunikasi, Informasi dan Edukasi (KIE), melalui spanduk dan pemberian masker serta penyemprotan hand sanitizer. Selain itu juga akan dilaksanakan proses belajar sebagai bentuk edukasi permasalahan pembelajaran anak dan peningkatan nilai religius anak melalui mengaji dan berdo'a. Sebagai bentuk pengembangan dan penerapan edukasi yang inovatif dan kreatif anakanak juga diedukasi terkait materi yang mampu meningkatkan kapasitas anak baik itu literasi dan numerasi serta visualisasi terhadap anak. Anak juga diajarkan untuk mencintai lingkungannya dengan menanam bibit menggunakan media botol bekas serta mengolah sampah botol bekas dan kertas bekas menjadi barang berguna seperti hiasan dan juga kotak pensil. Semua kegiatan yang dilakukan juga bekerjasama dengan pihak terkait baik mitra serta instansi pemerintahan seperti Dinas P3AP2KB Provinsi NTB, Dinas Pemberdayaan Perempuan dan Perlindungan Anak (DP3A) Kota Mataram dan BPBD Provinsi NTB dan Kota Mataram. Kerjasama yang dilakukan berupa koordinasi kegiatan dan sinkronisasi kegiatan yang dapat dilakukan bersama seperti distribusi KIE, distribusi masker serta pembentukan Forum Anak Kelurahan gomong. Detail kegiatan yang dilakukan dapat dilihat pada Gambar 1.

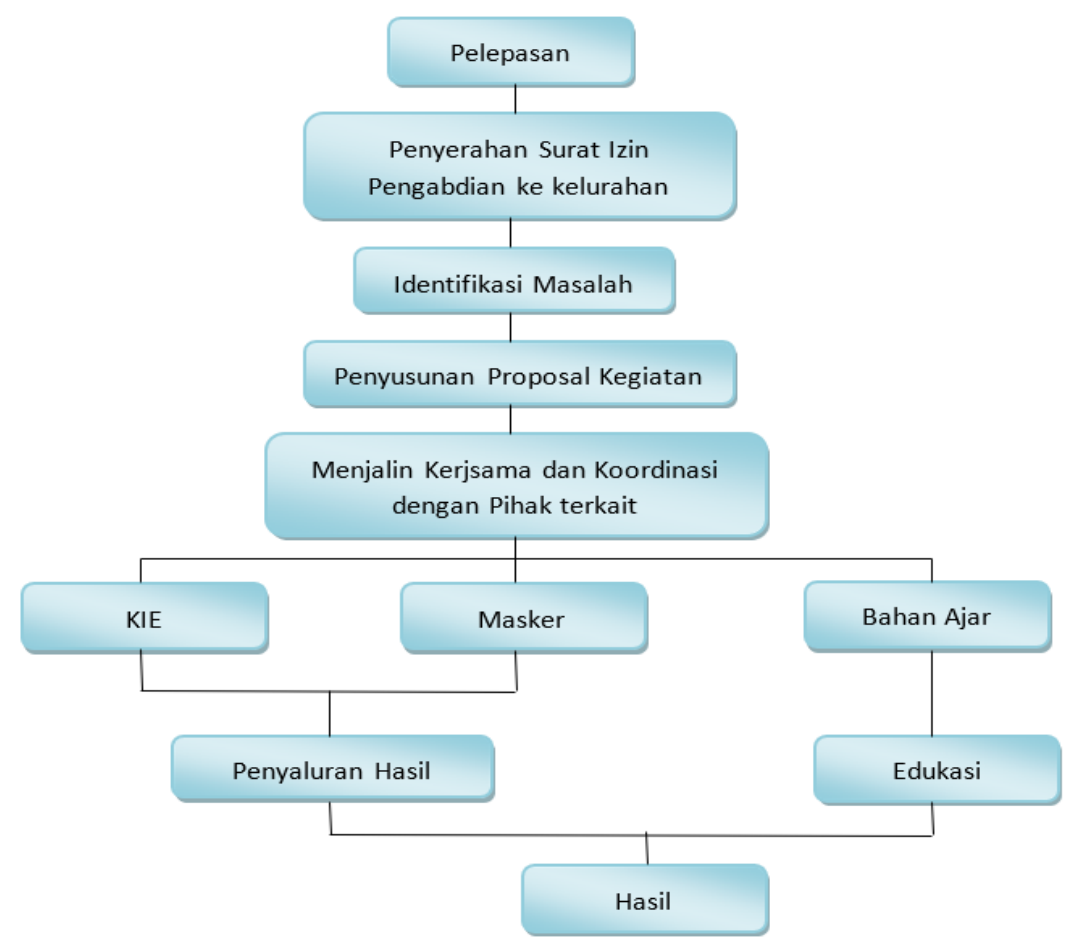

Gambar.1. Alur Pelaksanaan Kegiatan Pengabdian Masyarakat 


\section{Identifikasi Masalah}

Berdasarkan latar belakang masalah yang ada di kelurahan Gomong maka diidentifikasikan permasalahan, solusi dan bentuk kegiatan yang dilakukan melalui kegiatan Pengabdian Masyarakat yang terdapat dalam Tabel 1 berikut:

Tabel 1. Program Kegiatan Pengabdian Masyarakat

\begin{tabular}{|c|c|c|c|}
\hline No. & Permasalahan & Solusi & Kegiatan Yang Dilakukan \\
\hline 1. & $\begin{array}{l}\text { Penerapan protokol } \\
\text { kesehatan yang masih minim } \\
\text { di masyarakat dan anak-anak }\end{array}$ & $\begin{array}{l}\text { Optimalisasi sosialisasi dan } \\
\text { edukasi terkait penerapan } \\
\text { protokol kesehatan selama } \\
\text { pandemi covid-19 }\end{array}$ & $\begin{array}{l}\text { Sosialisasi secara langsung, edukasi } \\
\text { melalui spanduk edukatif, KIE } \\
\text { edukatif, dan pembagian masker }\end{array}$ \\
\hline 2. & $\begin{array}{l}\text { Pemahaman masyarakat dan } \\
\text { anak-anak yang }\end{array}$ & $\begin{array}{l}\text { Optimalisasi sosialisasi dan } \\
\text { edukasi terkait Covid- }\end{array}$ & $\begin{array}{l}\text { Sosialisasi secara langsung, edukasi } \\
\text { melalui spanduk }\end{array}$ \\
\hline & masih minim terkait Covid-19 & $\begin{array}{l}19 \text { kepada masyarakat dan } \\
\text { anak-anak }\end{array}$ & $\begin{array}{l}\text { edukatif, KIE edukatif, dan pembagian } \\
\text { masker }\end{array}$ \\
\hline 3. & $\begin{array}{l}\text { Minimnya edukasi kepada } \\
\text { anak-anak yang masih } \\
\text { kesulitan mendapatkan } \\
\text { edukasi dikarenakan } \\
\text { pembelajaran jarak jauh }\end{array}$ & $\begin{array}{l}\text { Memberikan edukasi kepada } \\
\text { anak-anak dengan cara yang } \\
\text { ramah anak dan sesuai dengan } \\
\text { keinginan anak }\end{array}$ & $\begin{array}{l}\text { Edukasi terkait literasi seperti membaca } \\
\text { dan menulis. Edukasi numerik seperti } \\
\text { berhitung. Edukasi terkait mengenal } \\
\text { hewan, sayur dan buah. Edukasi terkait } \\
\text { bahasa inggris. Edukasi dengan cara } \\
\text { menggambar dan mewarnai } \\
\text { serta edukasi religius seperti mengaji dan } \\
\text { belajar do'a. }\end{array}$ \\
\hline 4. & $\begin{array}{l}\text { Kreatifitas anak mengatasi } \\
\text { permasalahan lingkungan } \\
\text { yang ada }\end{array}$ & $\begin{array}{l}\text { Memberikan } r \text { edukasi } \\
\text { pengolahan sampah bekas } \\
\text { untuk barang berguna dan } \\
\text { digunakan sebagai media } \\
\text { tanam }\end{array}$ & $\begin{array}{l}\text { Edukasi terkait memanfaatkan sampah } \\
\text { kertas dan botol plastik menjadi hiasan } \\
\text { dan tempat pensil. Edukasi terkait } \\
\text { pembibitan sayur menggunakan botol } \\
\text { bekas }\end{array}$ \\
\hline
\end{tabular}

\section{Edukasi}

Edukasi yang dilakukan ini merupakan langkah atau solusi dalam mengatasi permasalahan yang telah disebutkan dalam latar belakang diatas. Edukasi yang dilakukan berfokus kepada masyarakat dan anak-anak di Kelurahan Gomong. Kegiatan yang dilakukan berupa memberikan edukasi kepada masyarakat dan anak-anak terkait Protokol Kesehatan dan Covid-19 melalui beberapa cara yaitu secara langsung maupun dengan melalui media berupa alat Komunikasi, Informasi dan Edukasi (KIE), melalui spanduk dan pemberian masker serta penyemprotan hand sanitizer. Selain itu juga akan dilaksanakan proses belajar sebagai bentuk edukasi permasalahan pembelajaran anak dan peningkatan nilai religius anak melalui mengaji dan berdo'a. Sebagai bentuk pengembangan dan penerapan edukasi yang inovatif dan kreatif anakanak juga diedukasi terkait materi yang mampu meningkatkan kapasitas anak baik itu literasi dan numerasi serta visualisasi terhadap anak. Anak juga diajarkan untuk mencintai lingkungannya dengan menanam bibit menggunakan media botol bekas serta mengolah sampah botol bekas dan kertas bekas menjadi barang berguna seperti hiasan dan juga kotak pensil. Edukasi itu sendiri dilakukan dengan pendekatan yang humanis dan ramah anak. Berikut kegiatan yang dilakukan:

\section{a. Edukasi Covid-19 melalui KIE}

Di tengah pademi covid-19, masyarakat dan khususnya anak-anak melakukan segala aktivitasnya dari rumah. Oleh karena itu, penulis memberikan KIE edukatif terkait kegiatan selama 
pandemi covid-19 yang dibagikan pada tiap-tiap anak agar edukasi lebih maksimal.

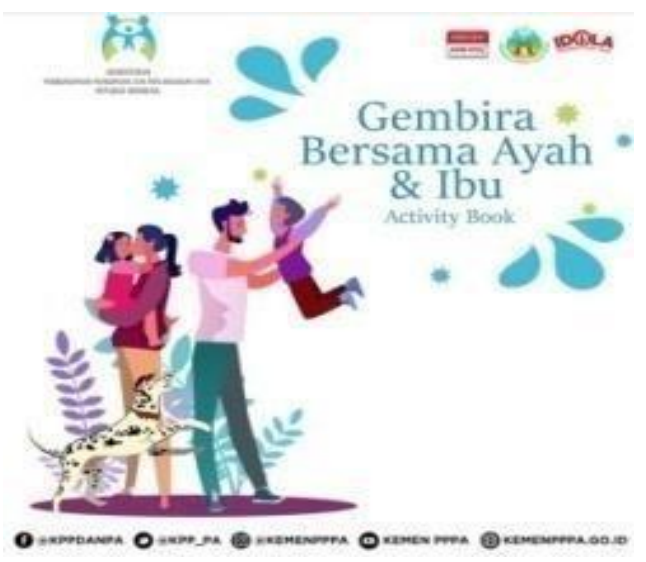

Gambar 2. KIE Edukatif

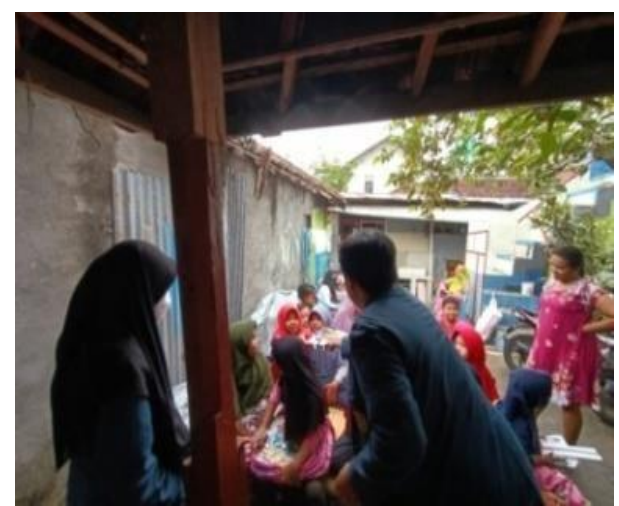

Gambar 3. Pembagian KIE kepada anak-anak

\section{b. Edukasi Protokol Kesehatan Covid-19 melalui Spanduk}

Pada era new normal pandemi covid-19 ini masyarakat dan anak-anak perlu diedukasi melalui hal-hal menarik seperti spanduk yang diletakan di tempat yang strategis dan mudah dibaca oleh masyarakat. Spanduk yang dijadikan edukasi ini adalah membahas terkait BERJARAK yaitu Bersama Jaga Keluarga Kita, berisi tentang ajakan kepada masyarakat dan anak-anak untuk menerapkan protokol kesehatan dengan mencuci tangan menggunakan sabun, menggunakan masker dan selalu menjaga jarak.

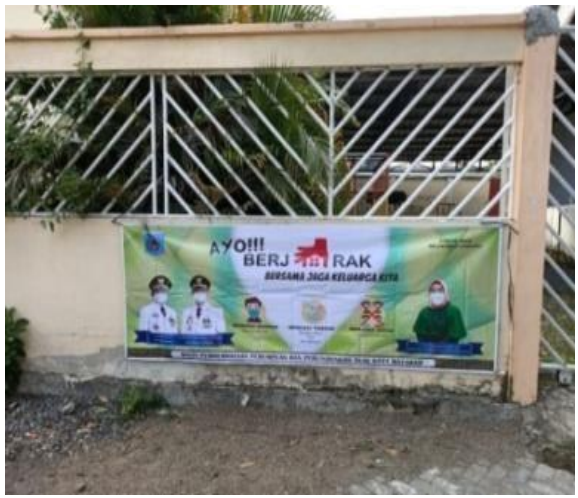

Gambar 4. Edukasi protokol Covid-19 melalui banner

\section{c. Edukasi Protokol Kesehatan Covid-19 melalui Pembagian Masker}

Mayoritas kalangan anak-anak tertarik dengan masker-masker yang menarik dan lucu. Oleh karena itu penulis membagikan masker yang unik dan lucu kepada anak-anak agar mereka suka menggunakan masker tersebut. Selain anak-anak masyarakat umum juga diberikan masker ini karena melihat kondisi di lokasi menunjukan bahwa masih banyak yang tidak menggunakan masker saat keluar rumah atau bertemu dengan tetangga.

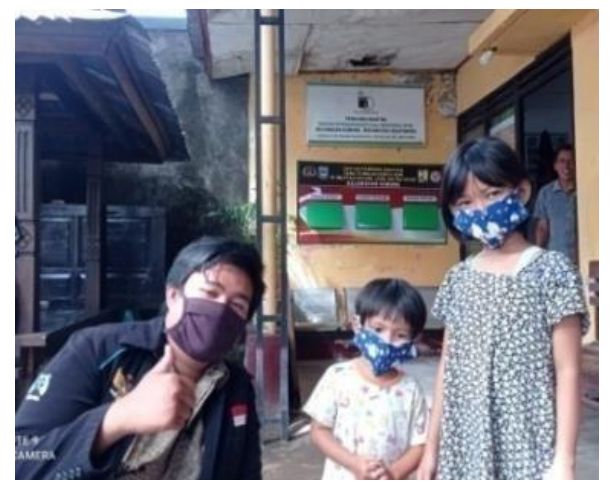

Gambar 5. Pembagian masker ke anak-anak

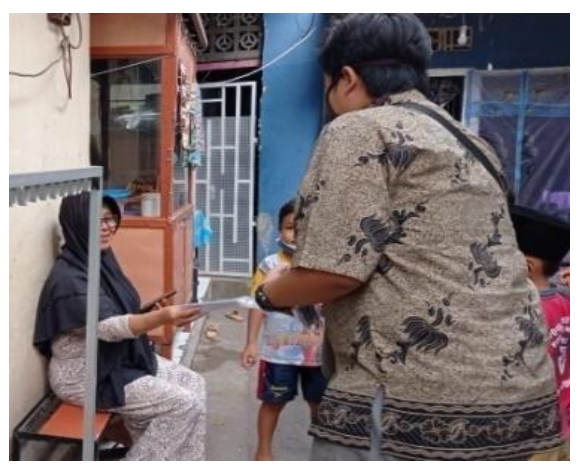

Gambar 6. Pembagian masker ke masyarakat 


\section{d. Edukasi Penggunaan Handsanitizer}

Penggunaan Hand Sanitizer ini sendiri merupakan upaya penerapan protokol kesehatan dalam memperkecil penyebaran Covid-19. Anak-anak perlu ditingkatkan pemahamannya terkait pentingnya membersihkan tangan dari segala bentuk aktivitas anak. Hal ini diterapkan saat sebelum anak-anak mulai belajar.

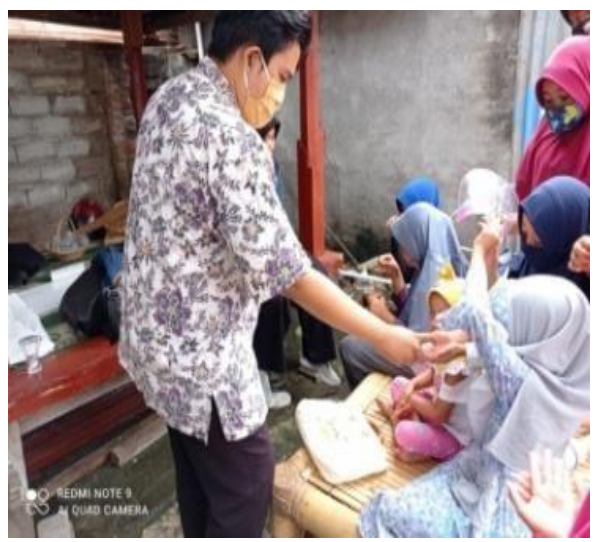

Gambar 7 Edukasi Penggunaan Handsanitizer

\section{e. Edukasi Nilai Religius Anak}

Dalam kegiatan pengabdian ini, dilakukan kegiatan edukasi penanaman nilai religius kepada anak. Hal ini dilakukan melalui kegiatan mengaji dan juga belajar terkait doadoa.

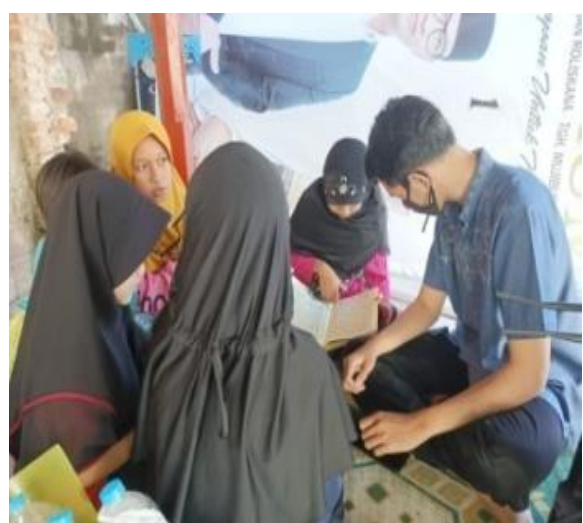

Gambar 8. Edukasi Nilai Religius Anak melalui Kegiatan Mengaji

\section{f. Edukasi Pembelajaran Anak}

Permasalahan yang ada yaitu masih minimnya kemampuan literasi dan numerik anak oleh karena itu penulis melakukan beberapa kegiatan dalam hal meningkatkan kemampuan belajar anak. Hal yang dilakukan berupa memberikan edukasi terkait membaca, menulis dan berhitung. Selain itu juga dilakukannya edukasi terkait pengenalan terhadap hewan, sayur dan buah serta edukasi bahasa inggris yang ramah anak.

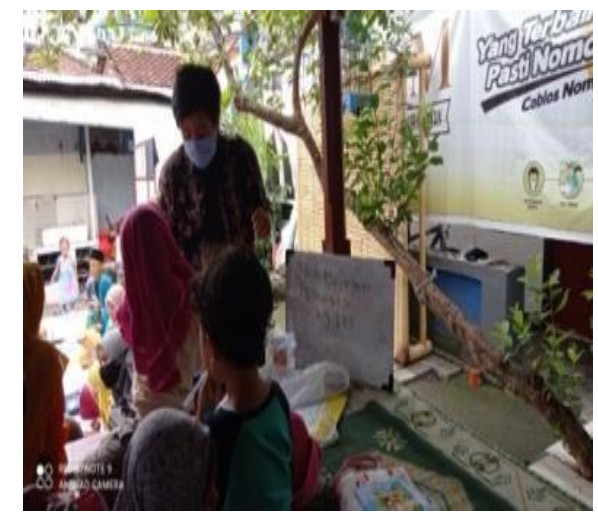

Gambar 9. Edukasi Pembelajaran Anak

\section{g. Edukasi Kreatifitas Anak}

Dalam meningkatkan kreativitas pada anak maka dilakukan beberapa upaya dengan menerapkan pembelajaran yang ramah anak dan sesuai dengan keinginan anak. Beberapa hal yang dilakukan adalah menggambar dan mewarnai. Selain itu kreatifitas anak ini juga mendorong edukasi terkait kepedulian anak terhadap lingkungan yaitu berupa pemanfaatan sampah menjadi barang yang berguna dan pembibitan sayur menggunakan media botol bekas.

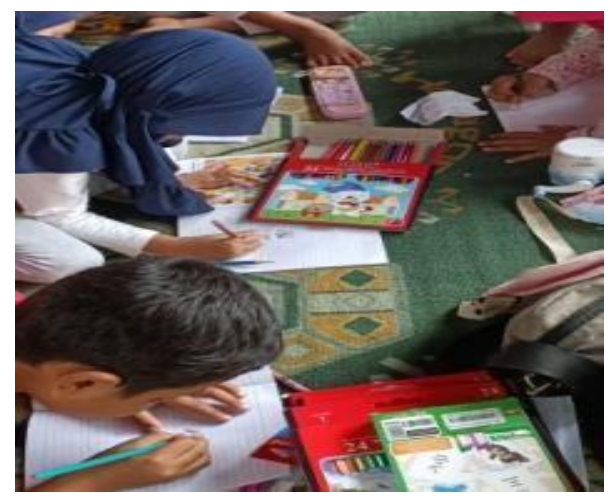

Gambar 10. Edukasi kreativitas anak melalui menggambar dan mewarnai 


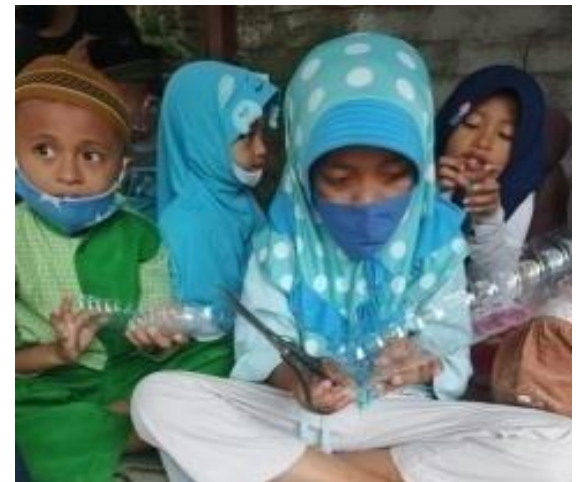

Gambar 11 Edukasi kepada anak tentang pembibitan sayur

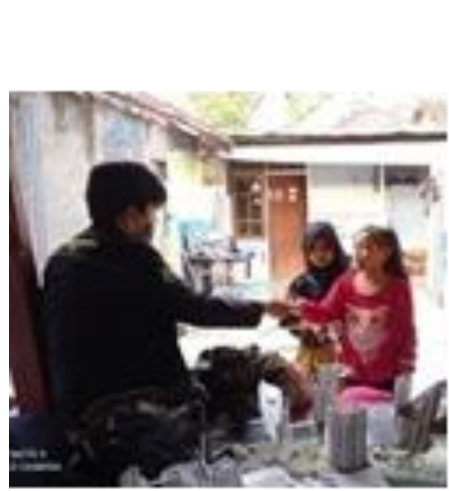

(a)

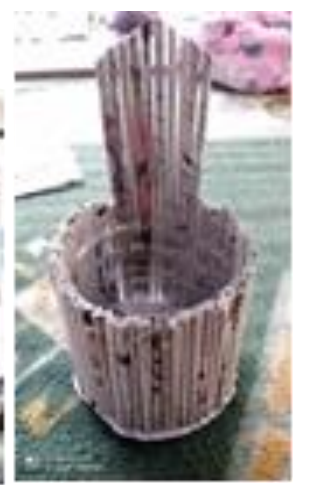

(b)
Gambar 12 (a). Edukasi kepada anak terkait pemanfaatan sampah (b) Hasil karya

\section{Kesimpulan}

Program Kegiatan Pengabdian Masyarakat Universitas Mataram di Kelurahan Gomong telah terlaksana. Hal yang didapatkan adalah teredukasinya masyarakat terkait Covid19 dan Protokol Kesehatan Pandemi Covid-19, Anak-anak juga teredukasi dengan adanya belajar setiap hari yang dibimbing oleh pelaksana kegiatan. Selain itu juga terbentuknya modul dan leaflet edukasi ramah anak yang akan dijadikan rujukan diterapkannya hal tersebut dalam menunjang sekolah ramah anak dan kota layak anak. Hal lain adalah terbentuknya Forum Anak Kelurahan Gomong yang kedepannya akan melanjutkan kegiatan tersebut

\section{Daftar Pustaka}

Fitriani, Nur Indah. 2020. Tinjauan Pustaka Covid19: Virologi, Patogenesis, dan Manifestasi Klinis. Jurnal Medika Malahayati. 4 (3): 194-201. Kemendikbud RI. 2020. Ragam Program Tayangan "Belajar dari rumah" di TVRI. https://www.kemdikbud.go.id/main/blog/20 20/04/ragam-tayangan-belajar-darirumahdi-tvri diakses: 10 Januari 2021.

Kemenkes RI. 2020. Situasi Terkini Perkembangan Novel Coronavirus (Covid-19). https://covid19.kemkes.go.id/situasiinfeksi-emerging/situasiterkiniperkembangan-coronavirus-diseasecovid-19-09-januari-2021 diakses: 10 Januari 2021.

Qodir, Abdul. 2017. "Humanistik" Teori Belajar Humanistik dalam Meningkatkan Prestasi Belajar Siswa. 4 (2):191.

Yulianto, Agus. 2016. Pendidikan Ramah Anak: Studi Kasus SDIT Nur Hidayah Surakarta. At-Tarbawi.Volume. 1(2): 137. 